\title{
Coulisses
}

Revue de théâtre

10 | Printemps 1994

Varia

\section{Embarquement pour le terminus du monde}

Jean-René Bouvret

\section{OpenEdition}

Journals

Édition électronique

URL : http://journals.openedition.org/coulisses/3737

DOI : $10.4000 /$ coulisses.3737

ISSN : 2546-9460

\section{Éditeur}

Presses universitaires de Franche-Comté

\section{Édition imprimée}

Date de publication : 1 juin 1994

Pagination : 15

ISSN : 1150-594X

\section{Référence électronique}

Jean-René Bouvret, «Embarquement pour le terminus du monde », Coulisses [En ligne], 10 | Printemps 1994, mis en ligne le 15 mars 2019, consulté le 27 octobre 2019. URL : http://journals.openedition.org/ coulisses/3737; DOI : 10.4000/coulisses.3737

Ce document a été généré automatiquement le 27 octobre 2019

Coulisses 


\section{Embarquement pour le terminus du monde}

Jean-René Bouvret

Chvéik au terminus du monde. D'après Le brave soldat Chvéik de Jarolav Hasek; Création et mise en scène de Wladyslaw Znorko.

Espace Planoise 14-15 janvier 1994.

Le Brave Soldat Chvéîk

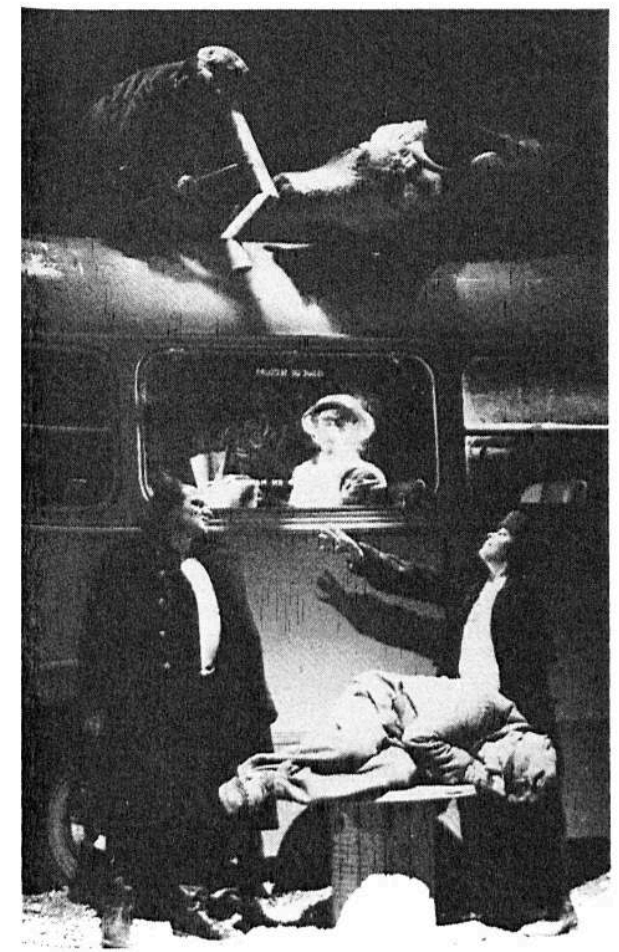

1 Du bruit, de la fumée, de la ferraille qui cogne, 
des crissements de roues contre les rails, une locomotive qui halète.

Des lumières blafardes,

nous sommes embarqués dans le wagon brinquebalant du train qui conduit à la guerre, du train de Wladislaw Znorko.

Il s'arrête parfois, le train,

la porte du wagon s'ouvre et laisse paraître des visages,

visages de ceux qui sont restés sur le quai,

tantôt avenants, tantôt encore plus désemparés que ceux des " voyageurs ",

des bouquets de fleurs,

une vache, un cochon,

une fanfare, une marchande de soupe et d'autres encore.

Réalité ? Rêve des « voyageurs »? Dans ces grands bouleversements,

on se demande laquelle des deux est la plus réelle : la réalité ou la fiction.

Tant la seconde l'emporte de vérité sur la première.

Et le train roule.

Et le wagon ballote ces corps, tous confondus, anonymes,

qui vont on ne sait où durant des kilomètres de voies ferrées.

Puis terminus.

La rencontre s'est faite.

On ne sait comment; de façon banale sûrement.

Et l'on se retrouve dans le campement de la défaite (ou de l'après, on ne sait pas).

Désemparé, pas même, vu qu'on l'était déjà complètement avant ;

Une défaite? Une Déculottée?

Le voyage a fait place à l'immobilisme.

Et la réalité, les rêves d'avant, font place à d'autres silhouettes et à d'autres mythes.

Un Don Quichotte blafard dans un vieil autobus.

La quête d'un bout de ciel bleu.

Des graviers dans un seau pour une musique de fin du monde, et le seau qui se vide, et le bruit des petits cailloux qui raclent la tôle et s'égrènent sur le sol.

Chvéik, le héros de l'histoire, se trouve superbement noyé au milieu de tout cela.

Du spectacle nous retenons une formidable image d'un terminus du monde. 